Київський університет імені Бориса

Грінченка,

galinasagan@gmail.com

Артем Кухто

Київський університет імені Бориса

Грінченка,

a.kukhto.asp@kubg.edu.ua

\title{
ДІЯЛЬНІСТЬ АНДРОНИКА СТЕПОВИЧА 3 РОЗВИТКУ СЕРБІСТИКИ В УКРАЇНI
}

У статті розкрито основні дані 3 життя та діяльності українського вченого 3 чорногорським корінням Андроника Степовича. Загалом показана роль вченого у розвитку славістики в Україні, і зокрема сербістики. Дослідження зроблено на аналізі архівних матеріалів, що зберігаються в Інституті рукописів Центральної наукової бібліотеки імені В. І. Вернадського НАН України. Завдяки діяльності А.Степовича українська наука мала можливість знайомитися 3 науковими досягненнями вчених гуманітаріїв Королівства сербів, хорватів і словенців (Королівство Югославія). Свої дослідження А. Степович неодноразово проводив в Сербії, Хорватії, Боснії і Герцеговині.

Ключові слова: Андроник Степович, сербістика, славістика, українськосербські зв'язки.

Із автобіографічних даних нам відомо, що Андроник Іоаникійович Степович - народився на Полтавщині в с. Лебединці Прилуцького повіту (нині Срібнянський район Чернігівської області) у 1856 р. (Степович, 1896: 1). Походив із малозаможної сільської родини. Фамільне прізвисько Степович належало предку А. Степовича, вихідцю з Чорногорії, який емігрував до Російської імперії в XVIII ст., коли там селилося багато південних слов'ян, котрі тікали від постійних військових нападів Османської імперії (Степович, 1896: 10).

До 4 класу включно проходив навчальний курс у Чернігівській гімназії. Виховувався у Сокиринцях в будинку заможного прилуцького поміщика Григорія Павловича Галагана разом з єдиним його сином Павлом Григоровичем, який за допомогою домашнього вчителя Федора Івановича Гур'єва, готувався до вступу в 6-й клас Київської гімназії. Тоді ж дванадцятирічний А. Степович готувався учителем Чернігівської 
гімназії Бобром до вступу у 2-й клас Київської гімназії, куди і вступив після успішно пройдених випробувань. У 1871 р., через 2 роки після смерті Павла Галагана, була заснована колегія його імені, куди за сприяння Григорія Галагана А. Степович був переведений 35 класу гімназії до 1 класу колегії, яку закінчив із золотою медаллю у 1875 p.

Інтерес до слов'янського фольклору проявився у майбутнього вченого ще під час навчання в Чернігові. Юнак також плекав цікавість до слов'янської історії, історії літератури та словесності, яку викладали в колегії Василь Дмитрович Ставецький - редактор педагогічного журналу «Женское образование», співавтор книги «Родная Старина», знавець історії руської словесності та Павло Ігнатійович Житецький відомий філолог, автор книг: «Очерк звуковой истории малорусского наречия», «Очерк литературной истории малорусского наречия» та ін (ДА м.Києва,185-1-585). Вчителі одразу примітили у свого вихованця глибокий інтерес до проблем слов'янства. Так, Василь Дмитрович Сиповський - знаний історик та педагог, співавтор книги «Родная старина», не тільки виявив підтримку інтересів А. Степовича, а навіть всіляко допомагав у його прагненні. Він постійно цікавився самостійними заняттями учня, шукав для нього необхідну літературу, часто розмовляв про хід його учнівської наукової роботи. Наприклад, він подарував А. Степовичу сербсько-російський словник П. Павловського, лекції Григоровича, а також навчальне видання «Краледворський рукопис» Корника (Степович, 1896: 330). Такий неформальний інтерес учителя до наукових уподобань учня, підтримка його інтересів, безумовно, стали вирішальними для дослідницьких уподобань майбутнього вченого-славіста. «Йому, - писав А. Степович, - я зобов'язаний надзвичайно за свій моральний розвиток, за ту привітну підтримку, яку я незмінно зустрічав у нього у тяжкі хвилини хитань і сумнівів. Він керував мною в усіх устремліннях, надіях молодого життя, у зародженні і розвитку тих чи інших наукових симпатій, у виробленні ідеалів і загального світогляду» (Степович, 1896: $330)$.

Тут в колегії А. Степович написав наукові роботи «Предисловие к речнику сербо-немо-латинскому Вука Караджича», «Словарь к сочинениям Яникия Космия» та ін (ІР НБУВ, 179-61-4). У 8 класі написав наукову роботу «Слово о полку Игореве и песни Краледворской рукописи и Зеленогорской», про яку П.Житецький 
написав: «Праця цінна щирістю молодого захоплення науковими інтересами. Можна сподіватися, що з часом зробиться людиною науки, якщо не зверне вбік» (IP НБУВ, 179-97-36).

31875 р. готувався до вступу у Київський університет та досліджував діяльність Михайла Бакуніна, творів Петра Лаврова та народовольця Олександра Михайлова. Погляди останнього хоч і на рік, сильно вплинули на А.Степовича, та надихнули на вивчення історичної науки (Р НБУВ, 179-1-3). У 1877 р. він надрукував свою наукову розвідку під назвою «Поэтические предания сербов о падении их царства. Три казацкие думы о турецкой неволе» (Степович, 1877).

У 1879 р. вступив до Київського університету на історикофілологічний факультет. Перший семестр навчання А.Степовичу не було що робити: славістику ще не викладали, обов'язкове вивчення латинської та грецької для першого року навчання він не потребував, адже ще до вступу досконально їх вивчив та міг вільно переводити 3 одного на інший, тому доводилося лише слухати лекції відомого українського історика Володимира Антоновича. В університеті А.Степович також вів активну громадську та просвітительську діяльністю, зокрема займався в нелегальному гуртку де ознайомився 3 соціалістичною теорією i навчаннями. На основі здобутих знань закликав університетську молодь до звільнення молодих дівчат від батьківської влади і опіки шляхом укладення фіктивних шлюбів і т.п. Спочатку до нього багато хто дослухався, завдяки самовпевненості i дару красномовства, але коли він став закликати молодь до ходіння в народ для пропаганди і навіть залишення університету для того, що б у ролі народних вчителів, фельдшерів та ін. влаштовувати терористичні вбивства урядників, чиновників та приставів, то більшість не сприйняли його ідей, а з 1-го випуску колегії П. Галагана за ним пішов тільки Павло Іванов, медик і один 3 кращих його товаришів, який родом був 3 Сибіру (ІР НБУВ, 179-1-4).

На другий семестр до університету влаштувався Олександр Котляревський, під науковим керівництвом якого А.Степович навчався слов'янознавству та написав запропоновану професором кандидатську дисертацію «Вацлав Болемир Небеский и значение его литературных трудов» (ІР НБУВ, Х-6428-6429-1). Восени 1879 р. О.Котляревський зі згоди факультету запропонував А.Степовичу місце на кафедрі для 
підготовки до професорства, проте цим намірам не судилося збутися через одруження А. Степовича та смерть О. Котляревського.

Після закінчення Київського університету викладав російську мову і словесність (українська була заборонена для викладання) в різних навчальних середніх закладах: Фундуклеївській жіночій гімназії, приватній гімназії Ващенко-Захарченко, Київському реальному та юнкерському училищах та 13-ти річній гімназії заміняючи П.Житецького, який виїхав до Петербурга на 2 роки. Окрім приватних уроків, він заміняв студентам вчителя військової гімназії Юрія Цвєтковського, члена старої української «Громади», навчав під його керівництвом невелику кількість студентів в приватному училищі.

Працюючи вчителем А. Степович не залишав наукову діяльність і постійно друкував свої розвідки, що стосувалися історії слов'янської літератури та словесності. Так, у 1882 р. вийшли друком «Славянские наречия», переклад і примітки яких були зроблені ще у 1879-80 pр., «Этюды в новой чешской литературе», «Франьо Кухач и его сборник югославянских песен», а в 1886 р., коштом Київського слов'янського товариства вийшла книжка «Очерк истории чешской литературы» за яку отримав премію ім. Толстого разом із знімком Краледворского рукопису (IP НБУВ, 179-1-6). На отримані кошти А. Степович здійснював неодноразові поїздки до слов'янських земель, результатами яких стала праця, яку він написав у Белграді «Очерки истории сербохорватской литературы», і видав у Києві 1899 р. У 18881893 pр. А. Степович склав 2 книги науково-літературного збірника «Славянская бесіда» $\mathrm{i}$ «Рассвет», для яких сам здійснював переклади $\mathrm{i}$ писав статті. Готував бібліографічні огляди для Воронезьких «Филологических записок», читав практично все, що видавалося слов'янськими та європейськими мовами. Ці огляди містили анотації і фактично мікрорецензії на монографії та збірники, що стосувалися історії, культури, літератури слов'ян. Це були публікації, присвячені слов'янській літературі, фольклору, біографічні нариси та оглядові статті для енциклопедичних видань. У архіві А. Степовича зберігаються статі за ці роки, які стосувалися питань російсько-польських історичних взаємин (IP НБУВ, 179-92). та діяльності Г.П. Галагана (IP НБУВ, 179126). Багато перекладає з слов'янських мов (чеської, сербо-хорватської, болгарської). 
У 1888 р. А.Степович керував з'їздом чеських вчителів, керівником якого спочатку був П.Т. Лубенець, після нього керівництво було доручено Г.М. Крижановському і після его смерті - А. Степовичу. 3 того часу А.Степович почав керувати чеськими училищами в трьох районах Волинської губернії.

У 1892 р. А.Степович, після прочитання в університеті пробної лекції «Найголовніші напрямки в новій чеській словесності», отримав звання професор-доцента на кафедрі слов'янської філології Київського університету. У 1894 р. А. Степович почав читати лекції та вести практичні заняття для студентів славістів 3-4-го курсу вступною лекцією «Борьба главнейших течений в новой сербской литературе». Обидві були надруковані в «Университетских известиях» (IP НБУВ, 179-1-7).

У 1893 р. А. Степович був запрошений Г. Галаганом на посаду директора колегії П. Галагана, що дало можливість звільнитися від турбот про матеріальні потреби для забезпечення великої сім’і i викладати в Київському університеті слов'янознавство та на Вищих вечірніх жіночих курсах, заснованих Аделаїдою Володимирівною Жекуліною. Ось як він сам згадував про це: «Я мушу визнати, - говорив А. Степович, - що цю честь прийняв я не без тривалих гірких роздумів, неминучих через трудність завдання і несприятливого для мене збігу обставин і умов. Рішення це, повторюю, я прийняв не без тривалої боротьби, і боротьби важкої з самим собою, не без сильних вагань бо тягар, який я прийняв на себе - далеко не такий зручний. Обов'язок любові і відданості до дорогого закладу, що виховав мене, - говорив він, - змусили мене нарешті не тільки прийняти принадні для будьякого сина нашої «alma mater» пропозиції..., але і присвятити всього себе, всі сили і здібності найвищому розквіту цього закладу» (ЦДІАК України, 1475-1-20-22)

3 ініціативи А. Степовича в Колегії починає видаватися «Ежегодник Коллегии Павла Галагана», редактором і автором якого він був упродовж десяти років. Цьому виданню А. Степович приділяв окрему увагу. Він писав: «всякий середній навчальний заклад, який себе поважає, зобов'язаний не тільки ознайомлювати суспільство через публікації з усіма обставинами свого внутрішнього життя, а по можливості розповідати і про нудне і про літературно-педагогічну діяльність, аби показати, що особливий склад його не нидіє у 
бездіяльності застою, а навпаки сповнений прагнення вдосконалюватися як у справі чистої науки, так і в розробці навчальновиховних питань» (ЦДІАК України, 1475-1-20-22). Під керівництвом А. Степовича пройшло святкування 25-річчя Колегії, детально описане у відредагованому ним збірнику (Степович, 1896).

Тоді ж сільські товариства селища Макіївка Ніжинського повіту Чернігівської губернії і Лебединці Прилуцького повіту Полтавської губернії вибрали А. Степовича в почесні попечителі своїх училищ, а Київське педагогічне товариство до своїх членів. У члени історичного товариства Нестора Літописця А. Степович був обраний ще в 1886 р., а в 1925 p. став його почесним членом. Був обраний головою педагогічного радника жіночої приватної гімназії ім. Конотопської, а також став членом редакції журналу «Київська старина», для якого протягом 25 років його існування написав багато різних статей. У 1893 p. він надрукував працю «Нариси 3 історії слов'янських літератур» у якій містилися розвідки про сербських та чеських письменників (Саган, 2012). Друкувався в «Слов’янській енциклопедії» «Освічений» журналі Міністерства Народної просвіти, а також у «Филологических записках», «Слов'янських вістях» до самого закриття журналу в 1917 р. Регулярно публікував статті, присвячені проблемам перекладу («Заметки о переводах Алоиза Ирасека»), у архіві Степовича зберігаються начерки статей, які стосуються 1920-1930-х років («По поводу украинских переводов инославянской белетристики», «Як не треба перекладати 3 слов'янської мови на українську») (ІР НБУВ, 179-23).

За допомогою Київського слов'янського товариства А. Степович займався доброчинною діяльністю пересилаючи зібрані кошти тим слов'янським народам, які найбільше потребували допомоги. За це він часто отримував листи-подяки від своїх колег за кордоном, у яких йшлося про велику роль слов'янського товариства з Києва i А. Степовича особисто у справі допомоги південним слов'янам Боснії $\mathrm{i}$ Герцеговини (Саган, 2012: 75).

А. Степович завжди популяризував діяльність південнослов'янських вчених та літераторів, зокрема за його ініціативи 22 жовтня 1899 р. в Київському університеті відзначали п'ятидесятиріччя діяльності сербського поета Йована Йовановича (Змай). А. Степович багато їздив у наукові відрядження до Сербії, Хорватії, працював у бібліотеках та архівах Франції, Німеччини та Австрії, де містилися 
матеріали зі славістики, робив запити до інших іноземних бібліотек, які надсилали йому літературу (Саган, 2012: 75).

Після встановлення радянської влади в Україні А.Степович продовжував працювати в Київському університеті. Викладав у ньому славістичні курси, вів дослідницьку роботу в новоствореній Українській Академії наук, публікував рецензії та бібліографічні огляди у виданнях ВУАН (лише у 1926 р. видруковано 12 праць ученого). Серед неопублікованих праць привертають увагу «Слов'янські літературні етюди» (IP НБУВ, 179-25). Проте згодом свою діяльність на кафедрі йому довелося згорнути, оскільки 1924 р. за рекомендацією партійних органів кафедру ліквідували як «неактуальну» інституцію (Саган, 2012: 78). Утримування професора А. Степовича в Київському університеті проводилося по вищому 17-му розряду. Був членом комісій 3 виробництва остаточних випробувань студентам колишнього Київського університету при перетворенні його у Вищий інститут народної освіти імені М.П. Драгоманова.

Того ж року наукова громадськість відзначила 70-річчя 3 дня народження і 50-річчя наукової діяльності Андроника Іоаникійовича Степовича. Від будь-яких масштабних святкувань, зокрема пропозиції президента академії наук СССР В.І. Липського відмовлявся і обмежився написанням вітальної статті в «Филологических записках» Всеукраїнської Академії наук і письмовими поздоровленнями. Стаття 3 портретом ювіляра була надрукована у «Записках ВУАН». 3 привітаннями відгукнулися і зарубіжні колеги.

Останніми справами на педагогічній ниві були: викладання слов'янської філології аспірантам М.С. Грушевського при його кафедрі та викладання історії культури балканських народів в Київському інституті сходознавства. 3 цього ж року наукові роботи А. Степовича зосереджувалися виключно в Ленінградській академії. Комітет зі складання словника російської мови при Академії наук СРСР надрукував, чимало його статей в редакції літопису «Труд» під редакцією М.С. Державіна, багато з написаного знаходиться в домі вченого.

Помер Андроник Іоаникійович Степович 26 жовтня 1935 р. у Києві. Похований на Лук'янівському кладовищі (Проценко, 1994: 231). Разом $з$ його смертю славістика втратила відомого науковця в цій сфері, наступні представники славістичної науки з'явилися лише через 
десятиліття, а праці самого А.Степовича так i не були належно досліджені та опубліковані.

Висновки. Отже, за час свого життя А. Степович чимало праць присвятив дослідженню та популяризації серед широкого загалу історії та літератури слов'янських народів, їздив до них в бібліотеки та архіви, листувався та ділився своїми ідеями 3 відомими зарубіжними славістами, істориками та письменниками, допомагав матеріально тим людям, які того потребували. А. Степович як славіст та вчений займав визначне місце в наукових колах свого часу. У незалежній Україні інтерес до українських науковців кінця XIX - початку XX ст., як і до А. Степовича, значно виріс. Залишися не вивченими питання історичних поглядів А. Степовича, його ставлення до нововведень, які запроваджувала радянська влада в Україні, насамперед в науці та освіті. Мало вивчена громадська діяльність вченого. Таким чином, подальше дослідження життя i творчості науковця $\epsilon$ досить перспективним i важливим для української та світової науки загалом.

\section{ДЖЕРЕЛА I ЛІТЕРАТУРА}

Derzhavnyi arkhiv m. Kyieva, f. 185, op. 1, spr. 585. (Cyrillic)

Otchet o sostoianyy Kollehyy Pavla Halahana 1 oktiabria 1879 - 4 maia 1893

hh. - TsDIAK Ukrainy, f. 1475, op. 1. - Spr. 1737. (Cyrillic)

Protsenko L.A. Kyivskyi nekropol : putivnyk-dovidnyk; [red.: V. D. Muzyka,

V. F. Huzhva]. - Kyiv: Ukr. pysmennyk, 1994. - 336 s. (Cyrillic)

Stepovych A. (1897) 93 otzыva o noveishykh knyhakh po slavianovedenyiu

// Slavianskye Yzvestyia: [Otd. Ottysk yz «Fylolohycheskykh zapysok». - Voronezh. (Cyrillic)

Stepovych A.Y. Avtobyohrafycheskye dannыe // Instytut rukopysu Tsentralnoi naukovoi biblioteky imeni V. I. Vernadskoho NAN

Ukrainy, F. Kh. - Spr. 6428-6429. - 9 ark. (Cyrillic)

Stepovych A.Y. Aloys Yyrasek y zametky o eho perevodakh // Instytut rukopysu Tsentralnoi naukovoi biblioteky imeni V. I. Vernadskoho NAN Ukrainy, 1931. - F. 179. - Spr. 35. (Cyrillic)

Stepovych A.Y. Zhyzneopysanye (kratkoe) pr. Stepovycha A. Y. Posle 1930

h. // Instytut rukopysu Tsentralnoi naukovoi biblioteky imeni V. I.

Vernadskoho NAN Ukrainy, F. 179. - spr. 1, 9 ark. (Cyrillic)

Stepovych A. (1896). Yz vospomynanyi o D. Sypovskom (1843-1895 hh.) / /

Dvadtsatypiatyletye Kollehyy Pavla Halahana v Kyeve, (1 oktiabria 
1871 - 1 oktiabria 1896 hoda) / [pod red. dyr. Kol. P. H. A. Y.

Stepovycha]. K.: Typohrafyia Y. Y. Chokolova. (Cyrillic)

Stepovych A.Y. Ytohy 25-letyia zhyzny y deiatelnosty Kollehyy Pavla

Halahana v Kyeve // 25-letye Kollehyy Pavla Halahana v Kyeve. -

K., 1896. - S. 109-147. (Cyrillic)

Stepovych A.Y. K 25-letyiu smerty H.P.Halahana // Instytut rukopysu

Tsentralnoi naukovoi biblioteky imeni V. I. Vernadskoho NAN Ukrainy, 1888. - F. 179. - Spr. 126. (Cyrillic)

Stepovych A.Y. K voprosu o russko-polskykh ystorycheskykh otnoshenyiakh

// Instytut rukopysu Tsentralnoi naukovoi biblioteky imeni V. I.

Vernadskoho NAN Ukrainy, 1888. - F. 179. - Spr. 92. (Cyrillic)

Stepovych A. (1877). Poэtycheskye predanyia serbov o padenyy ykh tsarstva

/ Stepovych A. // Sbornyk statei y rasskazov dlia yunoshestva. - Spb., (Cyrillic)

Stepovych A.Y. Predyslovye $\mathrm{k}$ rechnyku serbo-nemo-latynskomu Vuka Karadzhycha. 1872 h. Uchenycheskaia rabota (2-y klass Kollehyy Pavla Halahana). Prylozhenye: «Bakon Stefan y dva anhela», 4 str. yz pechatnoho yzdanyia «Pesny, sobrannыe V. Karadzhychem» // IR NBUV, f. 179. - spr. 61. -4 ark. (Cyrillic)

Stepovych A.Y. Raboto po slovesnosty (domashnye) v IV klasse Kollehyy Pavla Halahana u prepodavatelia P.Y. Zhytetskoho 1874-1875 hh. IR NBU. - F. 179. - Spr. 97. (Cyrillic)

Stepovych A.Y. Slovianski literaturni etiudy // Instytut rukopysu Tsentralnoi naukovoi biblioteky imeni V. I. Vernadskoho NAN Ukrainy, 1888. F. 179. - Spr. 25. (Cyrillic)

Stepovych A.Y. Yak ne treba perekladaty z slovianskoi movy na ukrainsku // Instytut rukopysu Tsentralnoi naukovoi biblioteky imeni V. I. Vernadskoho NAN Ukrainy, 1931. - F. 179. - Spr. 23. (Cyrillic)

Sagan G.V. (2012). Yugoslov'yani u XX stolitti: monografiya; Institut ukraïns'koï arheologiï ta dzhereloznavstva imeni M.S. Grushevs'kogo NAN Ukraïni. - Kiev. - 567 s. (Cyrillic) 
Galyna Sagan - Artem Kuhto

\section{ANDRONIK STEPOVIC'S ACTIVITY IN THE DEVELOPMENT OF SERBIAN RESEARCH IN UKRAINE}

\section{Summary}

The article reveals the basic data from the life and work of the Ukrainian scientist with the Montenegrin roots Andronik Stepovych. Is shown the role of the scientist in the development of Slavic studies in Ukraine in general, and in particular Serbistics. The research was made on the analysis of archival materials stored in the Institute of Manuscripts of the Vernadsky Central Scientific Library of the National Academy of Sciences of Ukraine. Thanks to the activity of A. Stepovych, Ukrainian science was able to get acquainted with the scientific achievements of scientists of the humanities of the Kingdom of Serbs, Croats and Slovenes (Kingdom of Yugoslavia). A. Stepovych repeatedly conducted his research in Serbia, Croatia, Bosnia and Herzegovina. During his life A. Stepovych devoted many works to research and popularization among the general history and literature of the Slavic peoples. He worked in foreign libraries and archives, corresponded and shared his ideas with famous foreign Slavists, historians and writers, helped these people. who needed it. A. Stepovych as a Slavic scholar and scientist occupied a prominent place in scientific circles of his time. In independent Ukraine, interest in Ukrainian scientists of the late XIX - early XX centuries, as well as A. Stepovych has grown significantly.

Keywords: Andronik Stepovych, Serbistics (Serbian studies), Slavic Studies, Ukrainian-Serbian relations. 